\title{
Capitonnage surgery is effective in all types of pulmonary hydatid cysts
}

\author{
Omer Mothafar Hammodat* , Bassam Khalid Alhajjar** , Ahmad Mothafar \\ Hammodat $^{\star \star *}$, Okba F. Ahmed*, Rabea Salim Abd Aljabbar* \\ ${ }^{\star}$ Al-Jumhory Teaching Hospital , Mosul , ${ }^{\star \star}$ Department Of Surgery, College Of Medicine \\ , University Of Mosul , ${ }^{\star \star \star}$ Alkansaa Teaching Hospital , Mosul , Iraq \\ Correspondence: bassamkhhajj@uomosul.edu.iq
}

(Ann Coll Med Mosul 2021; 43 (2):109-114).

Received: $28^{\text {th }}$ March 2021; Accepted: $28^{\text {th }}$ June 2021.

\begin{abstract}
Background: Hydatid cyst still has worldwide distribution with many cases discovered yearly in endemic areas. It has a predilection to involve the liver and the lung. Capitonnage has been practiced long time to avoid postoperative complications mainly air leak in addition to empyema formation. It may be still controversy concerning the efficiency of capitonnage especially for complicated hydatid cyst which led us to evaluate.

Aim of the study: To assess the efficacy of capitonnage surgery in minimizing the postoperative complications and hospital stay in complicated and non complicated pulmonary hydatid cysts.

Patients and Methods: A prospective study has been done at the department of thoracic surgery in AlJumhory teaching hospital at right side of Mosul, Department of pediatric surgery in Al-Khansaa teaching hospital and in Al-Rabee private hospital at left side of Mosul / Iraq between February 2017 and December 2019. Totally 118 patients with hydatid cyst of lung, including all ages and on different types of complicated and non-complicated cysts were included for this study. Co-morbid diseases like acute myocardial ischemia and uncontrolled diabetes mellitus were excluded from our study. Patients were evaluated in responce to the gender, age, clinical presentation, cyst condition (size, site and where ruptured or not) and postoperative hospital stay. Enucleation of the $\mathrm{HC}$ and capitonnage were carried out for all patients. The patient followed for three months at monthly interval, then each year with the mean follow up of 22 months.

Results: One hundred eighteen patients with median age of 32 years were operated using capitonnage method. In this study $49(41.5 \%)$ of the patients found to have intact cyst and the remaining $69(58.5 \%)$ had ruptured cyst. We recorded the early postoperative complications which include air leak in 10 cases, Atelectasis 8, pneumothorax 3, wound infection 3 and Hemoptysis in 2 cases.

Conclusion: Capitonnage can decrease the incidence of air leak and shorten hospital stay in complicated and non-complicated lung hydatid cysts.
\end{abstract}

Keywords: Capitonnage, Lung cyst, hydatid.

$$
\begin{aligned}
& \text { جراحة التبجيد فعالة لكل انواع الاكياس المائية في الرئة }
\end{aligned}
$$

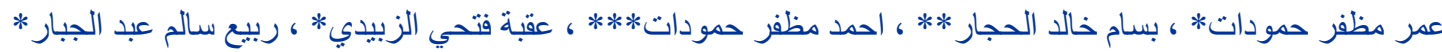

$$
\begin{aligned}
& \text { *مستشفى الجمهوري التعليمي ، الموصل ، **فرع الجراحة ، كلية الطب ، جامعة الموصل ، ***تمستثفى الخنساء التعليمي ، } \\
& \text { الموصل ، العر اق اقل }
\end{aligned}
$$

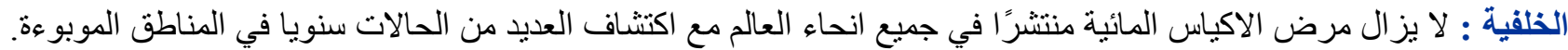

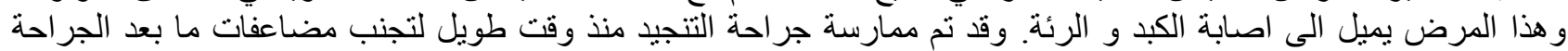

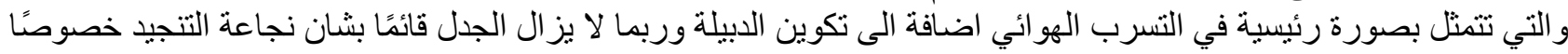

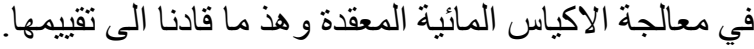

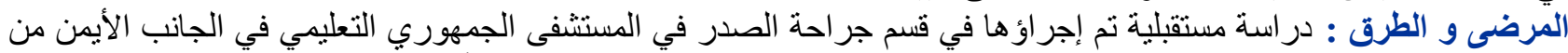

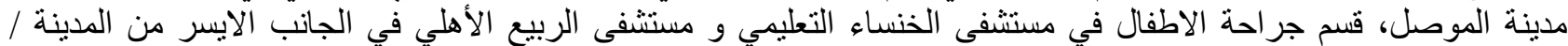

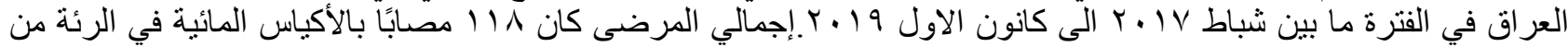

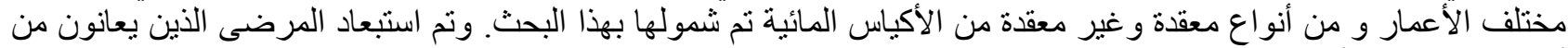

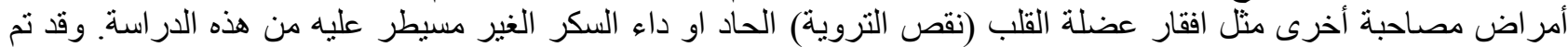


تقييم المرضى على أساس الجنس، العمر، وقت المراجعة، حالة الكيس (الحجم، الموقع، وهل تمزق الكيس ام لام) و الإقامة في

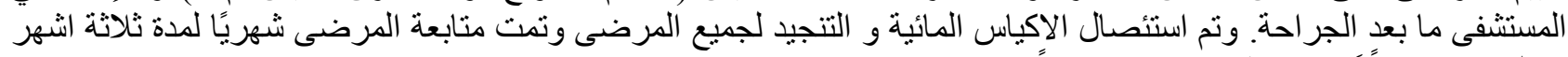

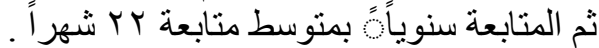

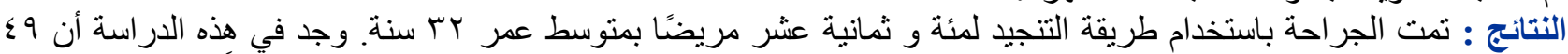

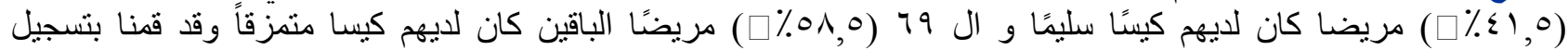

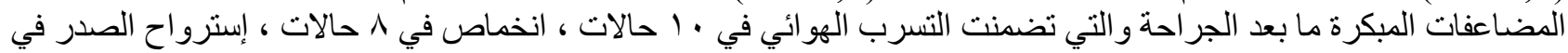

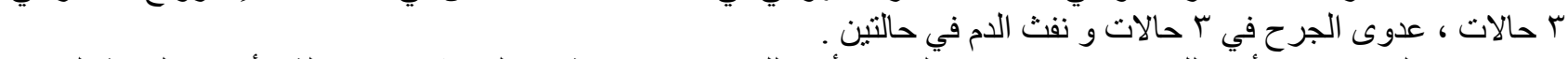

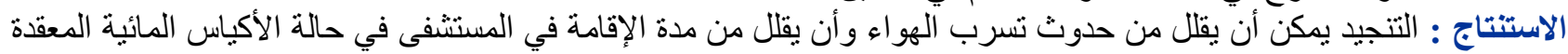

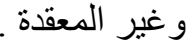

الكلمات المفتاحية : التنجيد ، كيس رئوي ، مائية .

\section{INTRODUCTION}

ydatid cyst (HC) still has worldwide distribution with many cases discovered yearly in endemic areas. Echinococcus granulosus causes this parasite illness. The metasestod variants of this parasite cause hydatid illness 1 . When hosts like dogs, wolves, jackals, and foxes devour the internal organs of temporary hosts like productive echinococcus cysts, they ingest the eggs that cause the sickness ${ }^{2}$. The eggs are then disseminated in the outer environment using the main host's stool. Embryos emerging out of the egg within the stomach as well as duodenum settle in the liver, lungs, and other organs through the portal vein and lymphatic system after being distributed by humans with water and food. Furthermore, they generate HCs in the area where they settle by assuming the form of larvae ${ }^{2,3}$.

The disease is usually asymptomatic. They can be found on chest $x$-rays by chance. The only symptom could be a dry cough. The cyst's excessive growth or rupture is linked to clinical symptoms. Cyst rupture can happen as a consequence of a natural occurrence, a traumatic event, or anthelmintic treatment. When cysts expand throughout the bronchial system, symptoms such as chest discomfort, cough, hemoptysis, urticaria, bronchospasm, and anaphylaxis can occur ${ }^{4,5}$.

Complete tracheal occlusion and abrupt death may occur depending on the size of the membrane that is expectorated. A rare but significant consequence is a cyst growing to reach pleural cavity. Pneumothorax, hydro-pneumothorax, and tension pneumothorax are the other possible complications ${ }^{5-7}$.

Direct radiography, as well as, computed tomography are used to diagnose pulmonary hydatid disease. In non-complicated cysts, round or oval, well-circumscribed, and homogenous density observation can be used to make a diagnosis ${ }^{8}$.
The appearance of parasite in the sputum under microscopic examination of a burst $\mathrm{HC}$ is a diagnostic approach. The method for demonstrating the link between the cysts and the bronchial tree is magnetic resonance imaging ${ }^{7}$.

Capitonnage has been practiced long time to avoid postoperative complications mainly air leak in addition to empyema formation. It may be still controversy concerning the efficiency of capitonnage especially for complicated hydatid cyst which led us to evaluate.

\section{Aim of the Study}

To assess the efficacy of capitonnage surgery in minimizing the postoperative complications and hospital stay in all types of pulmonary hydatid cysts.

\section{PATIENTS AND METHODS}

A prospective study has been done at the department of thoracic surgery in Al-Jumhory teaching hospital at right side of Mosul, Department of pediatric surgery in Al-Khansaa teaching hospital and in Al-Rabee private hospital at left side of Mosul / Iraq between February 2017 and December 2019. Totally 118 patients with hydatid cyst of lung, including all ages and on different types of complicated and non-complicated cysts were included for this study. Co-morbid diseases like acute myocardial ischemia and uncontrolled diabetes mellitus were excluded from our study. Patients were evaluated in response to the gender, age, clinical presentation, cyst condition (size, site and where ruptured or not) and postoperative hospital stay. Enucleation of the $\mathrm{HC}$ and capitonnage were carried out for all patients. The patient followed for three months at monthly interval, then each year with the mean follow up of 22 months.

Careful assessment was done to all patients before surgery, including routine hematological tests, hemagglutination assay (IHA) for echinococcosis, chest radiographs, computed 
tomography (for chest and brain) were done with the preparation of blood for surgery.

All patients under the study were operated under general anesthesia with the aid of single lung ventilation through endobronchial tube of double lumen. The thoracic cavity explored in all patients through standard muscle sparing posterolateral incision at 5th or 6th rib bed. Any pleural adhesions were freed from the lung; the cyst covered by mob soaked with chlorhexidineto prevents daughter cyst implantation in case of rupture. We incise the adventitia and then enlarge the incision by blunt dissection using scissor. We can use careful finger dissection to separate the cyst from the pericyst. After enucleation of the whole cyst, we do flushing of the cyst cavity with saline solution to check for obvious bronchial openings and close it. Then the cavity was obliterated with cappitonage using sutures to approximate the pericystic tissue and close the cyst cavity using polyglactin suture materials.

Pulmonary resection like lobectomy or segmentectomy neither performed nor needed in our patients. Some patients required decortication to release the pleural adhesions.

In all patients, a chest drainage catheter attached to an underwater seal drainage system was inserted posteriorly or anteriorly, in that sequence.

Albendazole was given postoperatively in a dosage of $10 \mathrm{mg} / \mathrm{kg}$ to prevent recurrence especially in ruptured cases for at least 6 months.

Patients with satisfactory results were discharged on 1st - 7th postoperative day and stitches removal after 10 days. All cases were followed for three months at monthly interval and then each year with clinical, as well as,radiological assessment. Data collection sheet was used to record all patients' information.

\section{RESULTS}

Table (1) shows that the study included 118 patients of pulmonary hydatid cyst cases, $73(61.9 \%)$ are males, $45(38.1 \%)$ are females.

Table (1): Distribution of study sample according to gender.

\begin{tabular}{|lll|}
\hline Gender & No. & $\%$ \\
\hline Male & 73 & $61.9 \%$ \\
\hline Female & 45 & $38.1 \%$ \\
\hline
\end{tabular}

Table (2) demonstrates the distribution of study sample according to age groups and reveals that, eight $(6.8 \%)$ of the patients are between 3-5 years of age (pre-school), followed by 42 (35.6\%) between 6-12 years (school age), 15 (12.7\%) between 13-18 years (adolescent), 40 (33.9\%) between 19-40 years (young adult), 12 (10.1\%) between 41-65 years (middle age), and 1 patient $(0.8 \%)$ was above 65 years (old adult). The mean age was 32.0 years with the range between $3-65$ years.

Table (2): Distribution of study sample according to age groups.

\begin{tabular}{|lll|}
\hline Age groups & No. & $\%$ \\
\hline Pre-school 3-5 years & 8 & $6.8 \%$ \\
\hline School age 6-12 years & 42 & $35.6 \%$ \\
\hline Adolescent 13-18 years & 15 & $12.7 \%$ \\
\hline Young adult 19-40 years & 40 & $33.9 \%$ \\
\hline Middle aged 41-65 years & 12 & $10.1 \%$ \\
\hline Old adult $>$ 65 years & 1 & $0.8 \%$ \\
\hline
\end{tabular}

Table (3) shows the distribution of study sample according to presentation and displays that, 53 $(44.9 \%)$ of patients from urban area, and other 65 (55.1\%) from rural area. More than one third (45 patients) (38.1\%) are asymptomatic, and 73 $(61.9 \%)$ of them were symptomatic (chest pain, cough andlor respiratory distress).

Table (3): Distribution of study sample according to presentation.

\begin{tabular}{|lll|}
\hline Presentation & No. & $\%$ \\
\hline Symptomatic & 73 & $61.9 \%$ \\
\hline Asymptomatic & 45 & $38.1 \%$ \\
\hline Residence & No. & $\%$ \\
\hline Urban & 53 & $44.9 \%$ \\
\hline Rural & 45 & $38.1 \%)$ \\
\hline
\end{tabular}

Table (4) illustrates the distribution of study sample according to site and shows that, forty-nine patients $(41.5 \%)$ had right lung involvement, 55 $(46.6 \%)$ had involved left lung and the rest 14 (11.9\%) with both lung involvement. Other organs involved in our patients, 22 patients had liver involvement, 3 patients with spleen involvement and only 2 patients had liver and spleen involvement.

Table (4): Distribution of study sample according to site.

\begin{tabular}{|l|ll|}
\hline Site & No. & $\%$ \\
\hline Right lung & 49 & $41.5 \%$ \\
\hline Left lung & 55 & $46.6 \%$ \\
\hline Both (Right and Left) & 14 & $11.9 \%$ \\
\hline
\end{tabular}


Table (5) demonstrates the distribution of study sample according to cyst condition and shows that, $49(41.5 \%)$ of the cases had intact cysts and extracted intact and the rest 69 (58.5\%) with ruptured cysts, 6 patients of the latter group presented with pneumothorax.

Table (5): Distribution of study sample according to cyst condition.

\begin{tabular}{|lll|}
\hline Cyst condition & No. & $\%$ \\
\hline Intact cyst & 49 & $41.5 \%$ \\
\hline Ruptured cyst & 69 & $58.5 \%$ \\
\hline
\end{tabular}

Table (6) demonstrates the distribution of study sample according to cyst size and shows that, during surgery the size of cysts was different, 18 patients $(15 \%)$ with cysts size of $5-10 \mathrm{~cm}, 11$ patients $(9.3 \%)$ with the size of cyst more than 10 $\mathrm{cm}$ and seven patients (5.9\%) presented with giant cyst.

All patients with different presentations underwent surgery with enucleation of the cysts and capitonnage.

Table (6): Distribution of study sample according to cyst size.

\begin{tabular}{|lll|}
\hline Cyst size & No. & $\%$ \\
\hline $\mathbf{5 - 1 0} \mathbf{~ c m ~}$ & 18 & $15 \%$ \\
\hline $\mathbf{> 1 0} \mathbf{~ c m}$ & 11 & $9.3 \%$ \\
\hline Giant cyst & 7 & $5.9 \%$ \\
\hline
\end{tabular}

Table (7) and figure (1) demonstrate the distribution of study sample according to air leakage and Hospital stay per day and shows that, out of 69 patients (of ruptured hydatid cyst) six patients $(5 \%)$ had prolonged air-leakage (more than one week), 65 (55\%) had to stay in hospital for one day, 9 (7.6\%) for two days and one $(0.8 \%)$ for seven days. It has been found that out of 49 patients (of non-ruptured hydatid cyst) four (3.4\%) developed persistent air leakage, 36 (30.5\%) had to remain in hospital for one day, 6 (5\%) for two days and one patient $(0.8 \%)$ for three days.

Table (7): Distribution of study sample according to air leakage and Hospital stay per day.

\begin{tabular}{|c|c|c|c|c|c|}
\hline & Air- & \multicolumn{4}{|c|}{ Hospital stay per day } \\
\hline & $\begin{array}{l}\text { leakage } \\
\text { No. (\%) }\end{array}$ & $\begin{array}{l}1 \text { day } \\
\text { No.(\%) }\end{array}$ & $\begin{array}{l}2 \text { days } \\
\text { No. }(\%)\end{array}$ & $\begin{array}{l}3 \text { days } \\
\text { No. }(\%)\end{array}$ & $\begin{array}{l}4 \text { days } \\
\text { No. (\%) }\end{array}$ \\
\hline Ruptured & $6(5.1 \%)$ & $65(55 \%)$ & $9(7.6 \%)$ & $0(0.0 \%)$ & $1(0.85 \%)$ \\
\hline $\begin{array}{l}\text { Non- } \\
\text { ruptured }\end{array}$ & $4(3.4 \%)$ & $36(30.5 \%)$ & $6(5.1 \%)$ & $1(0.85 \%)$ & $0(0.0 \%)$ \\
\hline
\end{tabular}

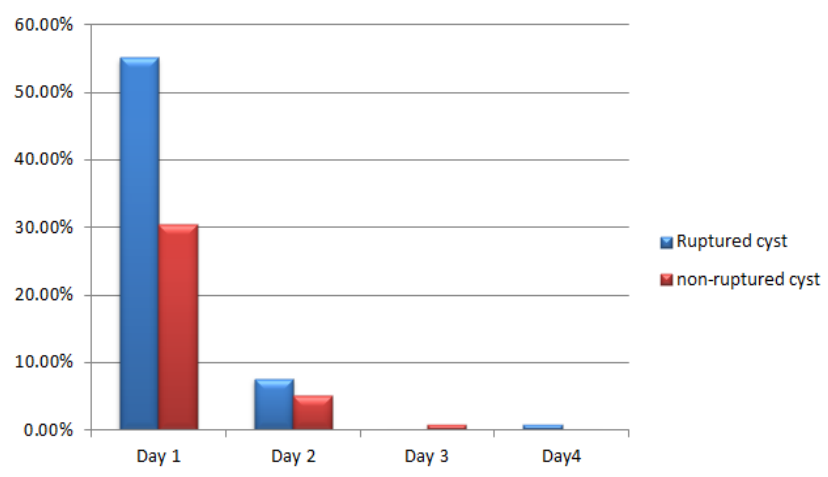

Figure (1): Distribution of study sample according to hospital stay per day

Table (8) shows the distribution of study sample according to day of chest tube removal and shows that, chest tube removal was from day 2 to day 7 post-operatively and most of them (86 patients) the chest tube was removed on day 3 post-operatively. In our series there was no morbidity and without any mortality.

Table (8): Distribution of study sample according to day of chest tube removal.

\begin{tabular}{|lll|}
\hline $\begin{array}{l}\text { The day of chest } \\
\text { tube removal }\end{array}$ & No. & $\%$ \\
\hline 2nd day & 4 & $3.4 \%$ \\
\hline 3rd day & 86 & $72.9 \%$ \\
\hline 4th day & 8 & $6.8 \%$ \\
\hline 5th day & 17 & $14.4 \%$ \\
\hline 6th day & 0 & $0.0 \%$ \\
\hline 7th day & 3 & $2.5 \%$ \\
\hline
\end{tabular}

Table (9) shows the distribution of study sample according to early post-operative complications and reveals that, the air leakage occurs in $8.5 \%$, followed by atelectasis $6.8 \%$, the rim of pneumothorax and wound infection occur in $2.5 \%$, and hemoptysis appears in 1.7\%. Empyema and bronchopleural fistula are not recorded.

Table (9): Early post-operative complications .

\begin{tabular}{lll|}
$\begin{array}{l}\text { Early post-operative } \\
\text { complications }\end{array}$ & No. & $\%$ \\
\hline Air leak & 10 & $8.5 \%$ \\
\hline Atelectasis & 8 & $6.8 \%$ \\
\hline Rim of pneumothorax & 3 & $2.5 \%$ \\
\hline Wound infection & 3 & $2.5 \%$ \\
\hline Hemoptysis & 2 & $1.7 \%$ \\
\hline Empyema & 0 & $0.0 \%$ \\
\hline Bronchopleural fistula & 0 & $0.0 \%$ \\
\hline
\end{tabular}


Table 10 shows the distribution of study sample according to symptoms of pulmonary hydatid cyst in the studied group and shows that, the cough is the main presenting symptom in $65.4 \%$ of patients, chest pain in $35.6 \%$, shortness of breath in $31.0 \%$, hemoptysis in $5.0 \%$, and sinus discharge in $2.5 \%$.

Table (10): Distribution of study sample according to symptoms of pulmonary hydatid cyst.

\begin{tabular}{|ll|}
$\begin{array}{l}\text { Symptoms of pulmonary hydatid } \\
\text { cyst in the studied group }\end{array}$ & $\%$ \\
\hline Cough & $65.4 \%$ \\
\hline Chest pain & $35.6 \%$ \\
\hline Shortness of breath & $31.0 \%$ \\
\hline Hemoptysis & $5.0 \%$ \\
\hline Sinus discharge & $2.5 \%$ \\
\hline
\end{tabular}

\section{DISCUSSION}

In this study, $73(61.9 \%)$ patients were symptomatic and 45 (38. \%) patients were asymptomatic. The symptomatic pulmonary hydatid disease commonly presents with cough either due to cyst compression effect or direct endobronchial rupture, shortness of breath and or chest pain. However, less common presentations have been encountered in our population, including hemoptysis, and sinus discharge (Table 10).

The mechanism of hemoptysis may be due to pressure erosion of a bronchus or an obstructive effect with bronchial infection ${ }^{4}$.

The mean age was 32 years which is consistent with findings of other studies who studied 75 patients with 30.2 years average age in their study . For this study $73(61.9 \%)$ are males and 45 are females representing (38.1\%).

Regarding residual cavity management all patients underwent residual cavity enucleation with bronchial opening closure and capitonnage.

All patients cured with no fatality similar to most relevant studies ${ }^{9,10}$.

For residual cavity, the results of Kuzucu et al. (2004) ${ }^{11}$, Hacubrachimoglu et al. (2003) ${ }^{12}$, Kanat et al. (2004) ${ }^{13}$ preferred the capitonnage method, where remaining cavity was closed by using separate tighten string sutures that is performed from the deepest plane to the surface, as these studies showed that capitonage procedure reduce morbidity and decrease the postoperative chest tube drainage period compared with non capitonnage while Halezeroglu et al., believed the obliteration of the post cyst resection cavity (capitonnage) is controversial ${ }^{14}$.

This study Air-leakage in Ruptured 6 (5\%) while Non-ruptured $4(3.4 \%)$ so a lot of reports including most of large series advocated the use of capitannage as part of the procedure to reduce the risk of prolonged air leak, development of empyema and residual space and therefore the hospital stay. We can see that most of the cases $(72.9 \%)$ in this study discharged home well after removal of chest drain on the 3rd postoperative day.

Capitonnage gives the total closure of the cavity, and operate as a second barrier against protracted air leakage in the prevention of the bronchial air leak ${ }^{15,16}$.

Goni et al., argued against capitonnage as they believed it added no benefit and increased complications such as the atelectasis ${ }^{17}$.

Our series capitonnage minimize air leak and shorten hospital stay in dramatic way. Sayir et al., believe that capitonnage may be of added value in reducing the risk of post-operative air leaks especially if it is performed in a non-infected or severely inflamed pericystic lung parenchyma ${ }^{18}$.

In our series, intact cyst $49(41.5 \%)$, ruptured cyst $69(58.5 \%)$ patients presented with ruptured cyst which is higher than that of Hamouri et al., a series conducted in 88 patients, where 32 of them presented with ruptured cyst representing (37\%) 19

Radiological improvement takes more than two weeks, the same as in the early period postoperatively; radiographs of chest of the patients had capitonnage usually showed a consolidated region at the site of operation; but radiological manage after 2 months illustrated normal radiological results or a thin fibrotic band, suggesting full obliteration of the cavity ${ }^{20}$.

Eight patients' developed atelectasis but resolved within two weeks, Yaldiz et al ${ }^{20}$ capitonnage was employed in 271 patients $(92.2 \%)$, and only 4 patients $(1.3 \%)$ developed atelectasis. We think that if capitonnage technique is applied carefully to the folding of peri-cystic tissue, then it will decrease the rate of atelectasis and distortion ${ }^{18}$. Our strategies we were asking the anesthetists to hyper inflate the lung after capitonnage to minimize atelectasis.

\section{CONCLUSION}

In our series, capitonnage minimize air leak and shorten hospital stay. And can be done in all type of pulmonary hydatid cyst.

\section{RECOMMENDATIONS}

We highly recommend capitonnage in hydatid cyst of lung hydatid, especially if done non infected cyst and perfect bronchial opening closure and good pre-operative preparation. 


\section{Ethical Issues}

The present study was approved by the Medical Research Ethics Committee, College of Medicine, University of Mosul. Additionally, written informed consent was obtained from all patients before the examination.

\section{Acknowledgment}

This study was supported by College of Medicine, University of Mosul, Iraq.

\section{REFERENCES}

1.Wen $\mathrm{H}$, Vuitton $\mathrm{L}$, Tuxun $\mathrm{T}$, Li J , Vuitton D, Zhang $W$, et al. , Echinococcosis: Advances in the 21st Century. Clin Microbiol Rev. 2019; 32(2):e00075-18. Published 2019 Feb 13. doi:10.1128/CMR.00075-18

2.Bhutani N, Kajal P. Hepatic echinococcosis: A review. Ann Med Surg (Lond). 2018; 36: 99-105. $\begin{array}{lll}\text { Published } & 2018 & \text { Nov }\end{array}$ doi:10.1016/j.amsu.2018.10.032

3.Zarrabi Ahrabi S, Madani R, Shemshadi B, Ranjbar Bahadori S, Hashemzadeh Farhang $\mathrm{H}$. Genetic Affinity of Echinococcus granulosus protoscolex in Human and Sheep in East Azerbaijan, Iran. Arch Razi Inst. 2020; 75(1): 4754. doi:10.22092/ari.2018.122733.1227

4. Mardani P, Karami MY, Jamshidi K, Zadebagheri $\mathrm{N}$, Niakan H. A Primary Pleural Hydatid Cyst in an Unusual Location. Tanaffos. 2017; 16(2):166169. PMID: 29308082; PMCID: PMC5749330.

5. Toleti S, Subbarao M, Dwarabu P. Hydatid disease of the lung presenting with hemoptysis and simulating a lung abscess. Trop Parasitol. 2012; 2(1):69-70. doi:10.4103/22295070.97248

6.Durkan A, Ozturk B, and Cakmak M. Analysis of pulmonary hydatid cysts underwent surgery. Biomedical Research. 2018; 29(17): 3384. DOI: 10.4066/biomedicalresearch.29-17-3384

7.Sarkar M, Pathania R, Jhobta A, Thakur BR, Chopra R. Cystic pulmonary hydatidosis. Lung India. 2016; 33(2): 179-191. doi:10.4103/09702113.177449

8. Siles-Lucas M, Casulli A, Conraths FJ, Müller N. Laboratory Diagnosis of Echinococcus spp. in Human Patients and Infected Animals. Adv Parasitol. 2017; 96: 159-257. doi:10.1016/bs.apar. 2016.09.003

9. Ahmadinejad M, Hashemi M, Azizallahi N. Evaluation of Prognostic Factors Associated with Postoperative Complications Following Pulmonary Hydatid Cyst Surgery. Open Respir Med J. 2020 Jul 21; 14: 16-21. doi: 10.2174/1874306402014010016. PMID: 32742527; PMCID: PMC7372731.
10. Ksia A, Ben Fredj M, Zouaoui A, Belghith M, Bokhary A, Nouri A. Capitonnage seems better in childhood pulmonary hydatid cyst surgery. GLOBAL SURGERY PAPER. 2020; 55(4): 752755, APRIL 01, 2020. Published: May 25, 2019. DOI: https://doi.org/ 10.1016/j.jpedsurg. 2019.05.009

11. Kuzucu A, Soysal O, Ozgel M, Yologlu S. Complicated hydatid cysts of the lung: Clinical and therapeutic issues. Ann Thorac Surg. 2004;77:1200-4

12. Haciibrahimoglu G, Çelik M, Senol C, Orki A, Urek S, Arman B. Surgical treatment of complicated hydatid cysts of the lung. Turkish Respir J. 2003; 4(3): 127-130.

13. Kanat F, Turk E, Aribas OK. Comparison of pulmonary hydatid cysts in children and adults. ANZ J Surg. 2004; 74(10): 885-889.

14. Halezeroglu S, Okur E, Tanyü MO. Surgical Management for Hydatid Disease. ThoracSurgClin. 2012; 22(3):375-385. https://doi.org/10.1016/j.thorsurg.2012.04.004

15. Kosar A, Orki A, Haciibrahimoglu G, Kiral H, Arman B . Effect of capitonnage and cystotomy on outcome of childhood pulmonary hydatid cysts. J ThoracCardiovascSurg. 2006; 132:560564.

16. Doğan R, Yüksel M, Cetin G, Suzer K, Alp M , Kaya $S$, et al. Surgical treatment of hydatid cysts of the lung: report on 1055 patients. Thorax. 1989; 44(3):192-199. https://doi.org/10.1136/thx.44.3.192

17. Goni MO, Karim MF, Alam MK, Chowdhury GA , Ahsan S . Capitonnage versus noncapitonnage surgery for pulmonary hydatid cyst: A head to head study. J Dhaka Med Coll. 2014; 23(1):94-101.

18. Sayir F, Cobanoğlu U, Sehitoğulları A, Bilici S . Our eightyear surgical experience in patients with pulmonary cyst hydatid. Int J ClinExp Med. 2012; 5(1):64-71.

19. Hamouri $S$, Al manasra $A$, Dradkeh $H$, Hammouri $\mathrm{H}$, Al zoubi $\mathrm{N}$, Novotny NM. Pulmonary hydatidosis patterns and clinical outcomes. AMJ. 2018; 11(2):135-142. https://doi.org/ 10.21767/AMJ.2018.3345

20. Yaldiz S, Gursoy S, Ucvet A, Yaldiz D, Kaya S. Capitonnage results in low postoperative morbidity in the surgical treatment of pulmonary echinococcosis. Ann Thorac Surg. 2012 Mar; 93(3):962-966.

doi: 10.1016/j.athoracsur.2011.11.011. Epub 2012 Jan 23. PMID: 22265202. 